\title{
Analisis Pemilihan Moda Transportasi Penduduk Kelurahan Pabuaran-Cibinong Pasca Pengoperasian Kereta Komuter (KRL) Jalur Nambo (Cibinong) - Citayam - Jakarta
}

\author{
Rosnaeni', Imam Buchori \\ Diterima : 21 November 2016 \\ Disetujui : 1 Desember 2017
}

\begin{abstract}
Congestion in Cibinong areas is mainly caused by highly vehicle usage, while the supply of road network is very limited. therefore it is needed a modal shift from private vehicles and optimizing the role of mass public transport (railway). This study aims to determine the modal choice of Pabuaran community, after the operational of commuterline (KRL) lane Nambo (Cibinong) - Citayam - Jakarta. This study uses a simple descriptive method to identify the factors that influence the mode choice of Pabuaran community, crosstab analysis method to identifying the movement of population, and binary logistic models to analyze the probability the change transport modes of Pabuaran community. The result of this study show that the probability of potential users for using commuterline are $91 \%$, it is influenced by several factors such as the distance of the settlement to the station, travel time, travel expenses, employment status and the existence of public transport/feeder to the station. The improvement of railway services in Cibinong station such as an increase in the frequency, timeliness, travel time, expected to attract the community to using rail services in their activities.
\end{abstract}

Keywords : urban railway, mode choice, crosstab, binary logit model

\section{ABSTRAK}

Kemacetan yang terjadi di daerah Cibinong dan sekitarnya disebabkan oleh penggunaan kendaraan pribadi yang tinggi, sedangkan supply jaringan jalan sangat terbatas, untuk itu diperlukan adanya pergeseran moda dari penggunaan kendaraan pribadi dengan pengoptimalan peran angkutan umum massal yaitu kereta api. Penelitian ini bertujuan untuk mengetahui sejauhmana perubahan pemilihan moda transportasi penduduk kelurahan Pabuaran, Cibinong pasca pengoperasian kereta komuter (KRL) Jalur Nambo (Cibinong) - Citayam - Jakarta kota. Penelitian ini menggunakan metode deskriptif sederhana untuk mengidentifikasi faktorfaktor yang mempengaruhi pemilihan moda transportasi penduduk, sedangkan untuk mengidentifikasi ciri pergerakan penduduk digunakan metode analisis crosstab dan binary logistic model untuk menganalisis peluang perubahan pemilihan moda transportasi penduduk kelurahan Pabuaran, Cibinong. Berdasarkan hasil analisis diketahui bahwa peluang beralihnya pengguna kendaraan pribadi menjadi pengguna layanan kereta api di stasiun Cibinong adalah 91\%, hal ini dipengaruhi oleh beberapa faktor seperti jarak pemukiman dengan stasiun, waktu tempuh perjalanan, biaya perjalanan, status pekerjaan dan keberadaan angkutan/feeder dari/ke stasiun. Dengan peningkatan pelayanan kereta api di stasiun Cibinong terutama peningkatan frekuensi, ketepatan waktu dan peningkatan waktu tempuh diharapkan mampu menarik minat penduduk untuk lebih memilih menggunakan layanan kereta api dalam melakukan aktivitasnya.

Kata Kunci : Kereta api perkotaan, pemilihan moda, crosstab, binary logit model

\footnotetext{
${ }^{1}$ Magister Pembangunan Wilayah dan Kota, Universitas Diponegoro

Kontak Penulis : roseneny86@gmail.com

${ }^{2}$ Magister Pembangunan Wilayah dan Kota, Undip, Semarang, Jawa Tengah
} 
Rosnaeni | Analisis Pemilihan Moda Transportasi Penduduk Kelurahan Pabuaran-Cibinong Pasca Pengoperasian Kereta Komuter (KRL) Jalur Nambo (Cibinong) - Citayam - Jakarta

\section{PENDAHULUAN}

Transportasi merupakan bagian yang tidak dapat dipisahkan dari kehidupan manusia. Transportasi diartikan sebagai usaha memindahkan, menggerakkan, mengangkut atau mengalihkan objek, dari suatu tempat ke tempat lainnya, dimana di tempat lain ini objek tersebut lebih bermanfaat atau dapat berguna dengan tujuan-tujuan tertentu (Miro, 2004). Peningkatan permintaan (demand) perjalanan yang tidak disertai dengan penyediaan pelayanan (supply) transportasi lambat laun akan memberikan dampak permasalahan transportasi yang meliputi aspek-aspek jaringan jalan, ekonomi, sosial, lingkungan dan keselamatan berlalu lintas (Vega and Reynold-Feighan, 2009). Indikasi dari permasalahan yang timbul dalam aspek-aspek tersebut berupa kemacetan, pemanfaatan badan jalan yang tidak sesuai, penggunaan kendaraan pribadi yang semakin meningkat, tingkat kecelakaan yang tinggi, konsumsi bahan bakar yang tidak efisien dan sebagainya.

Cibinong adalah salahsatu kecamatan dengan jumlah penduduk terbanyak di kabupaten Bogor, penduduknya sekitar 318.022 jiwa (Bps Kec.Cibinong, 2015). Letak Cibinong yang berada di antara Jakarta dan Bogor, membuat Cibinong sangat strategis untuk menjadi daerah pemukiman, perindustrian, sehingga pertumbuhan penduduknya semakin hari semakin meningkat. Selain itu Cibinong juga menjadi salah satu akses jalan menuju ke arah Bogor dari Jakarta atau sebaliknya. Hal tersebut membuat Cibinong menjadi sebuah daerah yang rawan kemacetan dan tingkat polusi yang tinggi. Tujuan dari penelitian ini adalah untuk melihat sejauhmana potensi perubahan pemilihan moda transportasi penduduk kelurahan Pabuaran, Cibinong dalam melakukan aktifitasnya setelah adanya pengoperasian KRL jalur Nambo (Cibinong) - Citayam - Jakarta.

\section{METODE PENELITIAN}

Penelitian ini merupakan penelitian deskriptif, dimana penelitian bertujuan untuk mendeskriptifkan situasi-situasi atau kejadian-kejadian secara sistematis, faktual, akurat mengenai fakta-fakta di lapangan (Supranto, 2003). Data yang dikumpulkan terdiri dari data primer dan data sekunder. Pengambilan data primer dilakukan dengan cara penyebaran kuesioner kepada penduduk Pabuaran dengan menggunakan teknik probability sampling. Probability sampling (Pemilihan sampel acak) adalah teknik pengambilan sampel yang memberikan peluang yang sama kepada setiap unsur (anggota) populasi untuk dipilih menjadi sampel (Sugiono, 2010). Teknik probabilitas yang digunakan adalah cluster random sampling. Data primer yang akan diambil berupa data untuk mengidentifikasi faktor-faktor yang mempengaruhi pilihan moda penduduk, seperti faktor usia, jenis kelamin, waktu tempuh perjalanan, biaya perjalanan, jarak pemukiman, jarak perjalanan dan lain-lain. Data responden yang diambil dilapangan selanjutnya akan dilakukan proses pengolahan seperti pengklasifikasian data yang terdiri atas editing, coding data dan analisis data baik dengan metode deskriptif maupun metode analisis. Proses ini dilakukan untuk mempermudah untuk mengolah data yang sudah ada ke tahapan analisis.

Dalam tahapan ini untuk mengidentifikasi ciri pergerakan penduduk akan digunakan metode dengan analisis crosstab terhadap faktor-faktor yang mempengaruhi pemilihan moda penduduk. Sedangkan untuk melihat potensi beralihnya pilihan moda penduduk yang semula menjadi pengguna kendaraan pribadi menjadi pengguna layanan kereta api di stasiun Cibinong akan digunakan metode regresi binary logistic (Yandong, 2014). 


\section{GAMBARAN UMUM WILAYAH STUDI}

\section{A. Kondisi Geografis dan Administrasi}

Kelurahan Pabuaran adalah salah satu kelurahan dari 12 kelurahan yang ada di kecamatan Cibinong, kabupaten Bogor. Kelurahan Pabuaran dengan bentangan lahan daratan, yang terletak pada ketinggian $220 \mathrm{~m}$ dpl dengan curah hujan rata-rata $2210 \mathrm{~mm} /$ tahun dan suhu udara $220 \mathrm{C}-300 \mathrm{C}$. Kelurahan Pabuaran terletak pada koordinat latitut 06.46258 oS dan longitut 106.846710E dengan luas wilayah 425,00 Km2, dengan batas wilayah seperti yang terlihat di peta berikut.
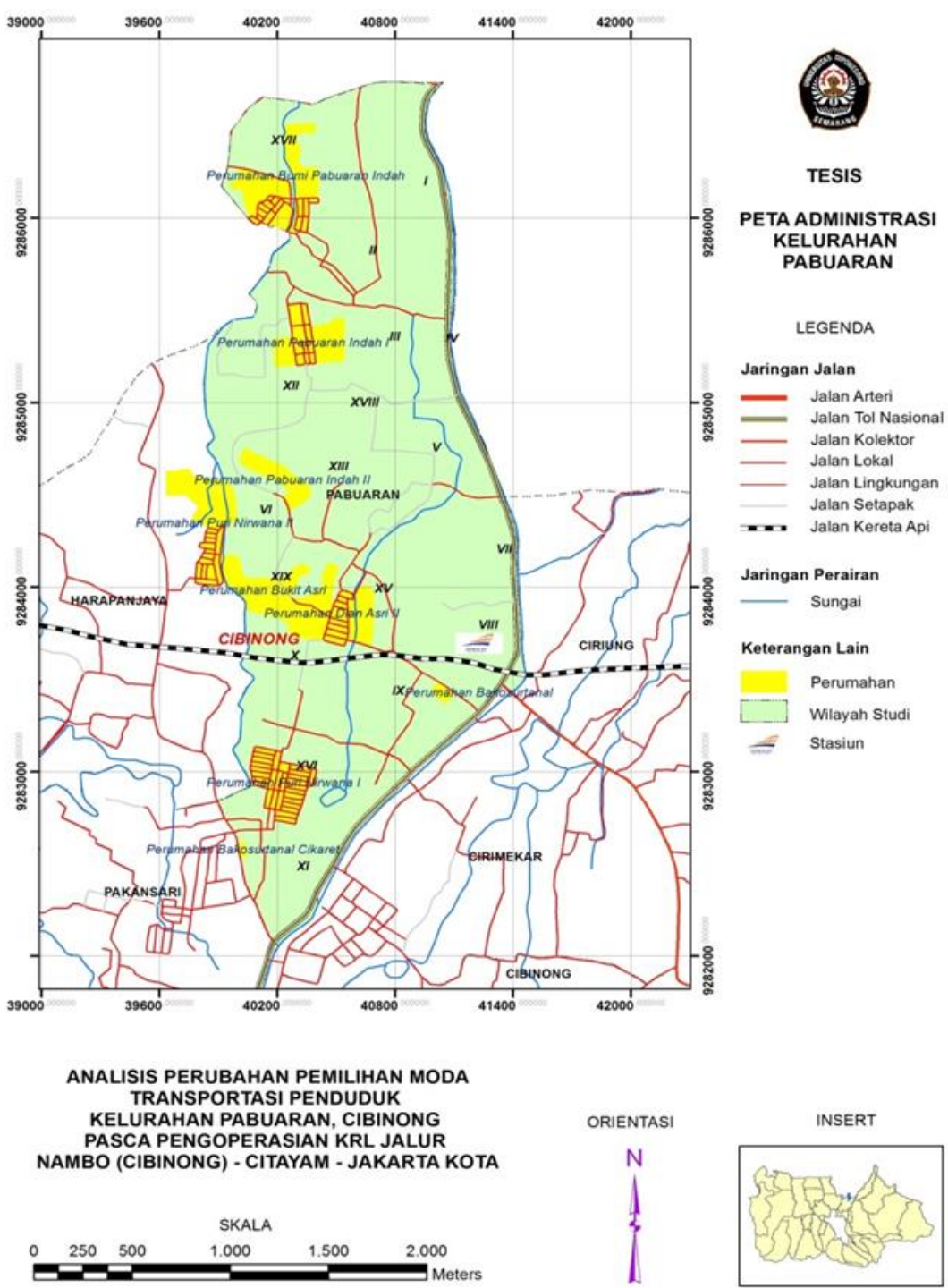

Sumber: Hasil Analisis, 2016

\section{GAMBAR 1 \\ PETA WILAYAH STUDI}

\section{B. Kependudukan dan perekonomian}

Berdasarkan data laporan tahunan kelurahan Pabuaran (2015), diketahui bahwa jumlah penduduk kelurahan Pabuaran, Cibinong tercatat sebanyak 68.885 jiwa yang terdiri atas 33.895 laki-laki dan 34.990 perempuan dan terdiri dari 17.028 KK. Kelurahan Pabuaran 
Rosnaeni | Analisis Pemilihan Moda Transportasi Penduduk Kelurahan Pabuaran-Cibinong Pasca Pengoperasian Kereta Komuter (KRL) Jalur Nambo (Cibinong) - Citayam - Jakarta

JPWK 13 (4)

terdiri 165 RT, 19 RW. Penduduk kelurahan memiliki mata pencaharian yang beranekaragam, antara lain dapat dilihat pada tabel I berikut.

Tabel I

Matapencaharian Penduduk Pabuaran

\begin{tabular}{|c|l|r|}
\hline No & \multicolumn{1}{|c|}{ Mata Pencaharian } & \multicolumn{1}{|c|}{ Jumlah } \\
\hline 1 & Pengusaha & 2.355 \\
\hline 2 & Pengrajin & 85 \\
\hline 3 & Buruh Industri & 10.381 \\
\hline 4 & Pertukangan & 738 \\
\hline 5 & Pedagang & 1.042 \\
\hline 6 & Pengemudi/Jasa & 314 \\
\hline 7 & Pegawai Negeri Sipil & 840 \\
\hline 8 & TNI/Polri & 703 \\
\hline 9 & Pensiunan/Purnawirawan & 341 \\
\hline
\end{tabular}

\section{Sarana dan Prasarana}

Dalam rangka memenuhi kebutuhan pelayanan dasar kepada masyarakat, pemerintah menyediakan sarana berupa sarana pendidikan, kesehatan, peribadatan, dan sarana transportasi. Sarana transportasi berupa angkot, bus antar kota dan layanan kereta komuter yang terletak di kelurahan Pabuaran, Cibinong.

\section{KAJIAN LITERATUR}

Transportasi merupakan gabungan dari dua definisi, yaitu sistem dan transportasi. Menurut Cascetta (2009), sistem transportasi dapat didefinisikan sebagai seperangkat elemen dan interaksi di antara mereka yang menghasilkan permintaan untuk perjalanan dalam daerah tertentu dan penyediaan jasa transportasi untuk memenuhi permintaan tersebut. Pada dasarnya permintaan atas jasa transportasi diturunkan dari kebutuhan seseorang untuk berjalan dari suatu lokasi ke lokasi lainnya untuk melakukan suatu kegiatan dan permintaan akan angkutan barang tertentu agar tersedia di tempat yang diinginkan (Setijowarno dan Frazila, 2001).

Pergerakan terbentuk akibat adanya aktifitas yang dilakukan bukan ditempat tinggalnya. Artinya keterkaitan antar wilayah ruang sangatlah berperan dalam menciptakan perjalanan dan pola sebaran tata guna lahan sangat mempengaruhi pola perjalanan orang (Tamin, 1997). Pola pergerakan di bagi dua yaitu pergerakan tidak spasial dan pergerakan spasial. Konsep pergerakan tidak spasial (tanpa batas ruang) di wilayah perkotaan, misalnya mengenai mengapa orang melakukan pergerakan, kapan orang melakukan pergerakan dan jenis angkutan apa yang digunakan. Sedangkan konsep mengenai ciri pergerakan spasial (dengan batas ruang) Artinya bahwa suatu perjalanan dilakukan untuk melakukan kegiatan tertentu di lokasi yang dituju, dan lokasi tersebut ditentukan oleh tata guna lahan kota yang bersangkutan. Pergerakan spasial dibedakan menjadi dua yaitu pola perjalanan orang dan perjalanan barang. Menurut Hunecke dkk (2007) perilaku perjalanan dipengaruhi oleh :

1. Lokasi : pola penggunaan lahan, sistem transportasi dan aksesibilitas pada suatu daerah akan mempengaruhi pengguna dalam memutuskan untuk memanfaatkan moda transportasi yang akan digunakannya. 
2. Karakteristik Sosial - demografi : usia, jenis kelamin, status sosial ekonomi atau tingkat pendapatan, tingkat pendidikan, komposisi rumah tangga, dan kepemilikan kendaraan mempunyai peranan penting dalam mempengaruhi perilaku perjalanan seseorang (Habib and Sasic,2014;Can,2013; Bhatta and Larsen, 2011).

3. Atribut budaya dan persepsi: kelompok budaya seseorang dapat mempengaruhi pilihan transportasi mereka (e.g., Lee et al., 2013; McMillan, 2007; Panter et al., 2010b).

Ketika memutuskan untuk melakukan pergerakan, seseorang akan dihadapkan pada pilhan moda apa yang akan digunakan. Seseorang bisa saja melakukan dengan kendaraan pribadi ataupun angkutan umum. Angkutan umum didefinisikan sebagai layanan yang disediakan oleh lembaga publik atau swasta yang tersedia untuk semua orang yang membayar dengan tarif yang ditentukan, yang tersedia di daerah pedesaan dan di daerah perkotaan, angkutan dapat berupa angkutan kota seperti bus, bus listrik, metro, dan moda lainnya yang beroperasi sesuai jadwal yang telah ditentukan (Vuchic, 2007).

Banyak faktor yang mempengaruhi pemilihan moda, menurut Whalen dkk, (2013) dalam penelitiannya menjelaskan ada beberapa faktor yang mempengaruhi seseorang dalam memilih moda yang digunakan untuk mencapai tujuannya, antara lain yaitu :

- Faktor sosio ekonomi: usia, jenis kelamin, tingkat pendidikan, status pekerjaan, pendapatan, status perkawinan, jumlah anggota keluarga, kepemilikan kendaraan dan sebagainya.

- Faktor karakteritik perjalanan, seperti biaya perjalanan, waktu perjalanan, jarak perjalanan, kenyamanan, keamanan, ketersediaan kendaraan, ketersediaan kendaraan umum, waktu menunggu.

- Faktor lingkungan seperti ketersediaan parkir, kepadatan lalu lintas, tempat tinggal, cuaca juga mempengaruhi pemilihan moda dalam melakukan perjalanan

\section{PEMBAHASAN}

\section{Pengklasifikasian data}

Sebelum dilakukan pengolahan data, terlebih dahulu akan dilakukan pengklasifikasian data, hal ini dilakukan untuk mempermudah dalam pengolahan data. Data yang didapat dari kuesioner akan diklasifikasian berdasarkan kategori misalnya kode 0 dan kode 1 . Pengklasifikasian ini dilakukan sesuai dengan metode analisis yang akan digunakan dalam mengolah data. Penelitian ini menggunakan metode crosstab/tabulasi silang dan metode regresi binary logistik.

\section{Hasil analisis}

Berdasarkan hasil analisis terhadap data responden diperoleh fakta bahwa dalam pemilihan moda transportasi penduduk Pabuaran, dipengaruhi oleh beberapa faktor antara lain yaitu: faktor sosio ekonomi yang meliputi usia, jenis kelamin, karakteristik perjalanan yang meliputi jarak perjalanan, biaya perjalanan, waktu tempuh perjalanan, waktu tunggu keberangkatan serta faktor lingkungan yang meliputi jarak pemukiman dari stasiun, keberadaan stasiun dekat dari tempat aktivitas dan ketersediaan angkutan/feeder dari/ke stasiun. 
Rosnaeni | Analisis Pemilihan Moda Transportasi Penduduk Kelurahan Pabuaran-Cibinong Pasca Pengoperasian Kereta Komuter (KRL) Jalur Nambo (Cibinong) - Citayam - Jakarta

Tabulasi Silang/crosstab

Analisis Crosstab/tabulasi silang digunakan untuk mengetahui variabel mana yang berpengaruh dan tidak berpengaruh terhadap pemilihan moda. Variabel dinyatakan berpengaruh jika diketahui angka signifikansinya ( $\mathrm{sig}<\mathrm{q}=0.05$ ) dengan menggunakan uji Chi Square.

TABEL II KATEGORI DATA

\begin{tabular}{|c|c|c|}
\hline No & Variabel & Kategori/Nilai \\
\hline A. & Variabel Dependent (Y) & \\
\hline & Jenis Pilihan moda & Kendaraan pribadi (0), Kereta api (1) \\
\hline B. & Variabel Independent (X) & \\
\hline 1 & Usia & $\begin{array}{l}\text { Usia 10-20 th (1), 21-30th (2), 31-40th (3), 41-50th (4), 51- } \\
\text { 6oth (5) }\end{array}$ \\
\hline 2 & Jenis kelamin & Laki-Laki (o), Perempuan (1) \\
\hline 3 & Pendidikan & SMA (1), D3 (2), S1(3) \\
\hline 4 & Pekerjaan & $\begin{array}{l}\text { Pegawai swasta/Karyawan (1), PNS(2), Wiraswasta (3), } \\
\text { Mahasiswa (4), Pedagang (5), IRT (6), Pelajar (7) }\end{array}$ \\
\hline 5 & Pendapatan & $\begin{array}{l}\text { Rp. o (1), <Rp. } 1.000 .000 \text { (2), Rp. 1.000.001-Rp.2.000.000 } \\
\text { (3), Rp. } 2.000 .001-\text { Rp.3.000.000 (4), Rp. 3.000.001- } \\
\text { Rp.4.000.000 (5), Rp. 4.000.001-Rp.5.000.000 (6), > Rp. } \\
\text { 5.000.000 (7) }\end{array}$ \\
\hline 6 & $\begin{array}{l}\text { Jumlah kendaraan pribadi } \\
\text { yang dimiliki }\end{array}$ & 1 unit (1), 2 unit (2), 3 unit (3), 4 unit (4) \\
\hline 7 & Jarak perjalanan & $\begin{array}{l}5-10 \mathrm{Km}(1), 11-15 \mathrm{Km}(2), 16-20 \mathrm{Km}(3), 21-25 \mathrm{Km}(4),>25 \mathrm{Km} \\
(5)\end{array}$ \\
\hline 8 & Biaya perjalanan & $\begin{array}{l}\text { Rp. } 5.000 \text { - Rp. } 10.000 \text { (1), Rp. } 10.001-\text { Rp. } 15.000 \text { (2), Rp. } \\
15.001-\text { Rp. } 20.000 \text { (3), lebih dari Rp. } 20.000 \text { (4) }\end{array}$ \\
\hline 9 & Waktu tempuh perjalanan & $\begin{array}{l}\text { Kurang dari } 30 \text { menit (1), 30-60 menit (2), 61-90 menit (3), } \\
91-120 \text { menit (4) }\end{array}$ \\
\hline 10 & Waktu tunggu keberangkatan & 5-10 menit (1), 15-30 menit (2), 31-60 menit (3) \\
\hline 11 & $\begin{array}{l}\text { Jarak pemukiman dengan } \\
\text { stasiun }\end{array}$ & $\begin{array}{l}\text { Kurang dari } 1 \mathrm{Km}(1), 1-2 \mathrm{Km}(2), 3-4 \mathrm{Km} \text { (3), lebih dari } 5 \mathrm{Km} \\
\text { (4) }\end{array}$ \\
\hline 12 & Keamanan Layanan & $\begin{array}{l}\text { Sangat Aman (1), Aman (2), Cukup Aman (3), Kurang Aman } \\
\text { (4), Tidak Aman (5) }\end{array}$ \\
\hline 13 & Kenyamanan Layanan & $\begin{array}{l}\text { Sangat Nyaman (1), Nyaman (2), Cukup Nyaman (3) Kurang } \\
\text { Nyaman, (4) Tidak Nyaman (5) }\end{array}$ \\
\hline 14 & $\begin{array}{l}\text { Keberadaan stasiun dekat dari } \\
\text { tempat aktivitas }\end{array}$ & Tidak Ada (1), Ada(2) \\
\hline 15 & $\begin{array}{l}\text { Keberadaan angkutan/feeder } \\
\text { dari/ke stasiun menuju tempat } \\
\text { aktivitas }\end{array}$ & Tidak Ada (1), Ada(2) \\
\hline
\end{tabular}

Sumber : Hasil Analisis, 2016

Hasil analisis crosstab terhadap ciri pergerakan penduduk berdasarkan faktor-faktor yang mempengaruhi pemilihan moda transportasi pada penduduk kelurahan Pabuaran, Cibinong dapat dilihat pada tabel 2 dibawah ini. 
TABEL III

ANALISIS CROSSTAB FAKTOR-FAKTOR YANG MEMPENGARUHI PEMILIHAN MODA PENDUDUK

\begin{tabular}{|c|c|c|c|c|c|}
\hline No & Variabel & $\mathbf{q}$ & Asymp sig. & $\begin{array}{l}\text { Contigency } \\
\text { Coefficient }\end{array}$ & Keterangan \\
\hline 1 & Usia & 0.05 & 0.000 & 0.550 & Signifikan \\
\hline 2 & Jenis Kelamin & 0.05 & 0.173 & 0.245 & Tidak signifikan \\
\hline 3 & Tingkat Pendidikan & 0.05 & 0.834 & 0.202 & Tidak signifikan \\
\hline 4 & Jenis Pekerjaan & 0.05 & 0.000 & 0.754 & Signifikan \\
\hline 5 & Pendapatan & 0.05 & 0.036 & 0.524 & Signifikan \\
\hline 6 & Jumlah kendaraan yang dimiliki & 0.05 & 0.990 & 0.234 & Tidak signifikan \\
\hline 7 & Jarak Perjalanan & 0.05 & 0.000 & 0.693 & Signifikan \\
\hline 8 & Biaya Perjalanan & 0.05 & 0.000 & 0.596 & Signifikan \\
\hline 9 & Waktu tempuh perjalanan & 0.05 & 0.000 & 0.575 & Signifikan \\
\hline 10 & Waktu tunggu keberangkatan & 0.05 & 0.010 & 0.409 & Signifikan \\
\hline 11 & Jarak pemukiman dengan stasiun & 0.05 & 0.000 & 0.613 & Signifikan \\
\hline 12 & Keamanan layanan & 0.05 & 0.686 & 0.290 & Tidak signifikan \\
\hline 13 & Kenyamanan layanan & 0.05 & 0.975 & 0.205 & Tidak signifikan \\
\hline 14 & $\begin{array}{l}\text { Keberadaan stasiun dekat dari tempat } \\
\text { aktivitas }\end{array}$ & 0.05 & 0.000 & 0.609 & Signifikan \\
\hline 15 & $\begin{array}{l}\text { Ketersedian angkutan/ feeder dari/ke } \\
\text { stasiun }\end{array}$ & 0.05 & 0.001 & 0.397 & Signifikan \\
\hline
\end{tabular}

Sumber : Hasil Analisis, 2016

Dari hasil analisis crosstab diketahui bahwa diantara 15 variabel yang di duga mempengaruhi pemilihan moda penduduk Pabuaran, Cibinong, hanya terdapat beberapa faktor yang benarbenar berpengaruh pada pemilihan moda mereka yaitu:

- Faktor usia, hasil analisis Crosstab yang menunjukkan nilai asymp sig. sebesar 0,000 dan nilai contingency coefficient sebesar 0.550, hal ini berarti usia seseorang signifikan mempengaruhi pilihan moda seeorang. semakin bertambah usia seseorang akan berpengaruh terhadap pilihan modanya, misalnya seseorang yang mendekati usia lanjut akan memilih menggunakan angkutan massal dalam hal ini kereta api dibandingkan menggunakan kendaraan pribadi (motor/mobil) dikarenakan kondisi fisik mereka yang kurang mendukung untuk menggunakan kendaraan pribadi (motor/mobil) untuk perjalanan jauh dengan kondisi jalanan yang macet dan lainnya.

- Jenis kelamin, hasil analisis Crosstab yang menunjukkan nilai asymp sig. sebesar 0,173 dan nilai contingency coefficient sebesar 0.245 , artinya jenis kelamin tidak memiliki hubungan atau berpengaruh terhadap pemilihan moda penduduk.

- Tingkat pendidikan, hasil analisis Crosstab yang menunjukkan nilai asymp sig. sebesar 0,834 dan nilai contingency coefficient sebesar 0.202, artinya tingkat pendidikan seseorang tidak memiliki hubungan atau berpengaruh terhadap pemilihan moda 
Rosnaeni | Analisis Pemilihan Moda Transportasi Penduduk Kelurahan Pabuaran-Cibinong Pasca Pengoperasian Kereta Komuter (KRL) Jalur Nambo (Cibinong) - Citayam - Jakarta

seseorang. Seseorang yang berpendidikan tinggi tidak selamanya menggunakan angkutan massal dalam hal ini layanan kereta api, meskipun mereka tahu penggunaan angkutan massal ini dapat memecahkan masalah kemacetan yang terjadi di daerah perkotaan, tetapi mereka lebih memilih untuk menggunakan kendaraan pribadi.

- Jenis pekerjaan, hasil analisis Crosstab yang menunjukkan nilai asymp sig. sebesar 0,000 dan nilai contingency coefficient sebesar 0.754, artinya jenis pekerjaan seseorang memiliki hubungan dan signifikan mempengaruhi pilihan moda transportasi yang digunakan. Penduduk Cibinong yang di dominasi oleh pegawai swasta yang memiliki tempat kerja di pusat kota Jakarta sehingga memerlukan transportasi yang dapat melayani pergerakan mereka setiap hari.

- Pendapatan, hasil analisis Crosstab yang menunjukkan nilai asymp sig. sebesar 0,036 dan nilai contingency coefficient sebesar 0.524 , hasil tersebut menunjukkan bahwa pendapatan seseorang memiliki hubungan dan signifikan mempengaruhi pilihan moda yang akan digunakannya. Hasil penelitian menunjukkan bahwa pengguna layanan kereta api di stasiun Cibinong mempunyai berbagai macam tingkat pendapatan, mulai dari pengguna yang mempunyai pendapatan < Rp. 2.000.000 sampai pengguna yang mempunyai pendapatan rata-rata $>$ Rp 2.000.000.

- Jumlah kendaraan yang dimiliki, hasil analisis Crosstab yang menunjukkan nilai asymp sig. sebesar 0,990 dan nilai contingency coefficient sebesar 0.234 , hasil tersebut menunjukkan bahwa jumlah kendaraan yang dimiliki seseorang tidak mempengaruhi pilihan moda yang digunakan. Dari hasil pengamatan diketahui bahwa meskipun memiliki kendaraan pribadi, tidak menutup kemungkinan orang tersebut menggunakan moda transportasi lain menuju tempat bekerja. Hal ini di dilakukan dengan berbagai pertimbangan misalnya faktor kemacetan yang terjadi di jalan raya, sehingga mereka lebih memilih menggunakan layanan kereta api sebagai sarana mereka dalam beraktivitas setiap harinya untuk menghindari kemacetan tersebut.

- Jarak perjalanan, hasil analisis Crosstab yang menunjukkan nilai asymp sig. sebesar 0,000 dan nilai contingency coefficient sebesar 0.693, hal ini berarti bahwa jarak perjalanan memiliki keterkaitan dan signifikan berpengaruh terhadap pemilihan moda seseorang, semakin jauh jarak perjalanan seseorang maka dia akan mempertimbangkan untuk menggunakan moda yang menurut mereka nyaman dan tidak memakan waktu lama. untuk daerah Jakarta dan sekitarnya, kemacetan yang sering terjadi dijalan raya membuat masyarakat lebih cenderung menggunakan layanan kereta api sebagai sarana mereka karena dapat menghemat waktu perjalanan yang akan ditempuh, selain itu jadwal keberangkatan kereta api yang sudah terjadwal memudahkan penumpang dalam memilih.

- Biaya perjalanan, hasil analisis Crosstab yang menunjukkan nilai asymp sig. sebesar 0,000 dan nilai contingency coefficient sebesar 0.596, artinya biaya perjalanan memiliki keterkaitan dan signifikan mempengaruhi pilihan moda penduduk, semakin murah biaya perjalanan yang dikeluarkan maka pengguna akan memilih untuk menggunakan layanan tersebut. Penggunaan kereta api komuter di stasiun Cibinong, dikenakan biaya perjalanan untuk jarak yang dekat penumpang hanya mengeluarkan 
Rp 2.000 untuk sekali perjalanan dan untuk jarak jauh hanya mengeluarkan kurang lebih $\mathrm{Rp} 6.000$ untuk sekali perjalanan.

- Waktu tempuh, hasil analisis Crosstab yang menunjukkan nilai asymp sig. sebesar 0,000 dan nilai contingency coefficient sebesar 0.575, artinya waktu tempuh yang dimiliki oleh suatu moda akan mempengaruhi pilihan moda penduduk. Penduduk akan memilih menggunakan layanan transportasi yang bisa menghemat waktu perjalanan mereka ke tempat aktivitas.

- Waktu tunggu keberangkatan, hasil analisis Crosstab yang menunjukkan nilai asymp sig. sebesar 0,010 dan nilai contingency coefficient sebesar 0.409, artinya waktu tunggu keberangkatan memiliki keterkaitan dan mempengaruhi pemilihan moda seseorang, seseorang akan memilih menggunakan moda transportasi yang terjadwal, tepat waktu dan kontinyu sehari sehingga memudahkan mereka untuk mengatur waktu dalam melakukan perjalanan.

- Jarak pemukiman, hasil analisis Crosstab yang menunjukkan nilai asymp sig. sebesar 0,000 dan nilai contingency coefficient sebesar 0.613, hal ini menunjukkan bahwa jarak tempat tinggal/pemukiman penduduk memiliki hubungan dan berpengaruh terhadap pilihan moda, dengan kata lain semakin dekat jarak pemukiman dengan stasiun kereta maka besar kemungkinan orang tersebut untuk menggunakan layanan kereta api karena untuk menjangkau fasilitas tersebut mereka tidak akan mengalami kesulitan.

- Keamanan layanan, hasil analisis Crosstab yang menunjukkan nilai asymp sig. sebesar 0,686 dan nilai contingency coefficient sebesar 0.290, hasil tersebut menunjukkan bahwa faktor keamanan layanan tidak mempengaruhi pilihan moda penduduk. Dari hasil pengamatan diketahui bahwa sebagian besar penduduk memilih menggunakan layanan kereta komuter di stasiun Cibinong tanpa melihat apakah layanan kereta tersebut benar-benar aman atau tidak, mereka memilih menggunakan kereta komuter di karenakan faktor kecepatan sampai di tempat aktivitas serta tarif perjalanan relatif lebih murah dibanding moda lainnya.

- Kenyamanan layanan hasil analisis Crosstab yang menunjukkan nilai asymp sig. sebesar 0,975 dan nilai contingency coefficient sebesar 0.205, hasil ini menunjukkan bahwa faktor kenyamanan layanan tidak mempengaruhi pilihan moda yang digunakan penduduk. Dari hasil pengamatan diketahui bahwa sebagian besar responden yang bekerja ke arah kota Jakarta, lebih memilih menggunakan layanan kereta api dalam melakukan aktivitas meskipun mereka harus berdesak-desakan dalam kereta. hal tersebut dilakukan untuk menghindari kemacetan di jalan raya.

- Keberadaan stasiun dekat dari tempat aktivitas, hasil analisis Crosstab yang menunjukkan nilai asymp sig. sebesar 0,000 dan nilai contingency coefficient sebesar 0.609, hal ini berarti keberadaan stasiun kereta dekat dengan tempat aktivitas akan mempengaruhi penduduk untuk menggunakan layanan kereta api di stasiun Cibinong. Pilihan penggunaan layanan ini tentu saja dengan asumsi bahwa dengan menggunakan kereta komuter mereka akan lebih gampang untuk menjangkau tempat bekerja mereka setiap harinya tanpa perlu untuk berpindah moda. 
Rosnaeni | Analisis Pemilihan Moda Transportasi Penduduk Kelurahan Pabuaran-Cibinong Pasca Pengoperasian Kereta Komuter (KRL) Jalur Nambo (Cibinong) - Citayam - Jakarta

JPWK 13 (4)

- Ketersediaan angkutan/feeder dari/ke stasiun, hasil analisis Crosstab yang menunjukkan nilai asymp sig. sebesar 0,001 dan nilai contingency coefficient sebesar 0.397, artinya ketersediaan angkutan/feeder dari/ke stasiun menjadi pertimbangan dalam menggunakan layanan kereta api, karena hal tersebut akan membantu atau memudahkan pengguna untuk menjangkau tujuan aktivitasnya.

\section{Analisis Regresi Binary Logistik}

Untuk mengkaji kemungkinan beralihnya pengguna moda kendaraan pribadi ataupun moda lainnya menjadi pengguna moda kereta api di stasiun Cibinong. Maka dilakukan analisis regresi binary logistik. Adapun variabel dependent dan independent akan diuraikan pada tabel.3 berikut.

TABEL IV

VARIABEL DEPENDENT DAN VARIABEL INDEPENDENT YANG DIGUNAKAN

\begin{tabular}{|c|c|c|c|}
\hline No & Variabel & Kategori/Nilai & Keterangan \\
\hline \multirow[t]{2}{*}{ A. } & Variabel Dependent & & \\
\hline & $\begin{array}{l}\text { Kesediaan Menggunakan } \\
\text { Layanan kereta api }\end{array}$ & Tidak (o), Ya (1) & \\
\hline $\mathrm{B}$ & Variabel Independent & & \\
\hline 1 & Usia & $\begin{array}{l}\text { Usia 10-20 th (1), 21-30th (2), 31-40th (3), 41- } \\
\text { 50th (4), 51-60th (5) }\end{array}$ & \\
\hline 2 & Jenis kelamin & Laki-Laki (0), Perempuan (1) & \\
\hline 3 & Pendidikan & SMA (1), D3 (2), S1(3) & $\begin{array}{l}\text { Non Academic } \\
\text { (SD,SMP,SMA sederajat). } \\
\text { Academic } \\
(\mathrm{D} 1, \mathrm{D} 2, \mathrm{D} 3, \mathrm{~S} 1, \mathrm{~S} 2)\end{array}$ \\
\hline 4 & Pekerjaan & $\begin{array}{l}\text { Pegawai swasta/Karyawan (1), PNS(2), } \\
\text { Wiraswasta (3), Mahasiswa (4), Pedagang } \\
\text { (5), IRT (6), Pelajar (7) }\end{array}$ & \\
\hline 5 & Pendapatan & $\begin{array}{l}\text { Rp. o (1), < Rp. 1.000.000 (2), Rp. 1.000.001- } \\
\text { Rp.2.000.000 (3), Rp. 2.000.001- } \\
\text { Rp.3.000.000 (4), Rp. 3.000.001- } \\
\text { Rp.4.000.000 (5), Rp. 4.000.001- } \\
\text { Rp.5.000.000 (6), > Rp. 5.000.000 (7) }\end{array}$ & $\begin{array}{l}\text { Low Income }< \\
\text { Rp.2.000.000, High } \\
\text { Income >Rp. } 2.000 .000\end{array}$ \\
\hline 6 & $\begin{array}{l}\text { Jumlah kendaraan pribadi } \\
\text { yang dimiliki }\end{array}$ & 1 unit (1), 2 unit (2), 3 unit (3), 4 unit (4) & Ratio/scale \\
\hline 7 & Jarak perjalanan & $\begin{array}{l}5-10 \mathrm{Km}(1), 11-15 \mathrm{Km}(2), 16-20 \mathrm{Km} \text { (3), } 21-25 \mathrm{Km} \\
(4),>25 \mathrm{Km} \text { (5) }\end{array}$ & \\
\hline 8 & Biaya perjalanan & $\begin{array}{l}\text { Rp. } 5.000 \text { - Rp. } 10.000 \text { (1), Rp. } 10.001-\text { Rp. } \\
15.000 \text { (2), Rp. } 15.001-\text { Rp. } 20.000 \text { (3), lebih } \\
\text { dari Rp. } 20.000 \text { (4) }\end{array}$ & $\begin{array}{l}\text { - Low cost < Rp. 20.000; } \\
\text { - High cost > Rp. } 20.000\end{array}$ \\
\hline 9 & Waktu tempuh perjalanan & $\begin{array}{l}\text { Kurang dari } 30 \text { menit (1), 30-60 menit (2), 61- } \\
90 \text { menit (3), 91-120 menit (4) }\end{array}$ & \\
\hline 10 & $\begin{array}{l}\text { Waktu tunggu } \\
\text { keberangkatan }\end{array}$ & $\begin{array}{l}\text { 5-10 menit (1), 15-30 menit (2), 31-60 menit } \\
(3)\end{array}$ & \\
\hline 11 & $\begin{array}{l}\text { Jarak pemukiman dengan } \\
\text { stasiun }\end{array}$ & $\begin{array}{l}\text { Kurang dari } 1 \mathrm{Km}(1), 1-2 \mathrm{Km}(2), 3-4 \mathrm{Km} \text { (3), } \\
\text { lebih dari } 5 \mathrm{Km}(4)\end{array}$ & \\
\hline 12 & Keamanan Layanan & $\begin{array}{l}\text { Sangat Aman (1), Aman (2), Cukup Aman (3), } \\
\text { Kurang Aman (4), Tidak Aman (5) }\end{array}$ & \\
\hline 13 & Kenyamanan Layanan & $\begin{array}{l}\text { Sangat Nyaman (1), Nyaman (2), Cukup } \\
\text { Nyaman (3) Kurang Nyaman, (4) Tidak } \\
\text { Nyaman (5) }\end{array}$ & \\
\hline
\end{tabular}




\begin{tabular}{|c|l|l|c|}
\hline No & \multicolumn{1}{|c|}{ Variabel } & \multicolumn{1}{c|}{ Kategori/Nilai } & Keterangan \\
\hline 14 & $\begin{array}{l}\text { Keberadaan stasiun dekat } \\
\text { dari tempat aktivitas }\end{array}$ & Tidak Ada (1), Ada(2) & \\
\hline 15 & $\begin{array}{l}\text { Keberadaan } \\
\text { angkutan/feeder dari dan } \\
\text { ke stasiun menuju tempat } \\
\text { aktivitas }\end{array}$ & Tidak Ada (1), Ada(2) & \\
\hline
\end{tabular}

Hasil Analisis, 2016

Setelah dilakukan analisis menggunakan spss dengan metode binary logistik, maka diperoleh data seperti pada tabel $\mathrm{V}$ berikut ini.

TABEL V

HASIL ANALISIS BINARY LOGISTIC POTENSI PENGGUNA KERETA API

\begin{tabular}{|c|l|r|r|}
\hline \multicolumn{1}{|c|}{ No. } & \multicolumn{1}{|c|}{ Variabel } & Koefisien Variabel & Nilai Signifikansi \\
\hline 1 & Jenis kelamin & 0.662 & 0.388 \\
\hline 2 & Usia & -0.003 & 0.905 \\
\hline 3 & Pendidikan & 0.175 & 0.814 \\
\hline 4 & Pendapatan & 2.004 & 0.047 \\
\hline 5 & Status pekerjaan & 0.403 & 0.028 \\
\hline 6 & Jumlah kendaraan yang dimilki & -1.285 & 0.093 \\
\hline 7 & Jarak pemukiman dengan stasiun & -2.284 & 0.000 \\
\hline 8 & Jarak perjalanan & -0.685 & 0.268 \\
\hline 9 & Biaya Perjalanan & -1.818 & 0.035 \\
\hline 10 & Waktu tempuh perjalanan & -2.226 & 0.003 \\
\hline 11 & Waktu tunggu keberangkatan & -0.126 & 0.900 \\
\hline 12 & Keberadaan moda dari stasiun ke tempat aktivitas & -1.654 & 0.164 \\
\hline 13 & Keberadaan stasiun dekat dari tempat aktivitas & -0.905 & 1.689 \\
\hline 14 & Keamanan Layanan & -1.712 & 0.537 \\
\hline 15 & Kenyamanan layanan & 15.557 & 0.032 \\
\hline & Constant & & 0.047 \\
\hline
\end{tabular}

Sumber: Hasil Analisis, 2016

Dari hasil analisis Binary Logistic, maka diperoleh koefisien variabel dan signifikansi setiap variabel. Dengan nilai $\alpha=0,05$, maka terdapat lima variabel yang signifikan (nilai signifikansi dibawah 0,05). Variabel tersebut adalah jarak pemukiman dengan stasiun kereta, waktu tempuh perjalanan, jenis pekerjaan, biaya perjalanan dan keberadaan angkutan/feeder dari/ke stasiun.

Untuk mereduksi variabel-variabel yang tidak signifikan dalam model, digunakan binary logistic dengan metode forward: LR. Hasil yang diperoleh dari metode tersebut dapat dilihat pada tabel VI dibawah ini. 
Rosnaeni | Analisis Pemilihan Moda Transportasi Penduduk Kelurahan Pabuaran-Cibinong Pasca Pengoperasian Kereta Komuter (KRL) Jalur Nambo (Cibinong) - Citayam - Jakarta

TABEL VI

HASIL ANALISIS BINARY LOGISTIC METODE FORWARD: LR

\begin{tabular}{|c|l|r|r|}
\hline No. & \multicolumn{1}{|c|}{ Variabel } & \multicolumn{1}{|c|}{ Koefisien Variabel } & Nilai Signifikansi \\
\hline 1 & Jarak pemukiman dengan stasiun & -1.582 & 0.000 \\
\hline 2 & Waktu tempuh perjalanan & -1.644 & 0.004 \\
\hline 3 & Biaya Perjalanan & -1.578 & 0.012 \\
\hline 4 & Keberadaan feeder dari/ke stasiun & -1.532 & 0.032 \\
\hline 5 & Status pekerjaan & 0.345 & 0.029 \\
\hline & Constant & $\mathbf{9 . 6 2 9}$ & $\mathbf{0 . 0 0 0}$ \\
\hline
\end{tabular}

Sumber: Hasil Analisis, 2016

Dari hasil analisis diatas, maka dapat disusun model yang menunjukkan probabilitas beralihnya pengguna kendaraan umum/pribadi menjadi pengguna layanan angkutan kereta api (KRL) di stasiun Cibinong sebagai berikut:

$$
\ln \left(\frac{P}{1-P}\right)=9,629-1,582 X_{1}-1,644 X_{2}-1,578 X_{3}-1,532 X 4+0,345 X_{5}
$$

Dimana:

- $\mathrm{P} \quad$ : Peluang Ya, responden beralih menggunakan layanan kereta api (KRL) stasiun Cibinong.

- 1- P : Peluang Tidak, responden tidak beralih menggunakan layanan kereta api (KRL) stasiun Cibinong.

- $\mathrm{X}_{1}$ : Jarak pemukiman dengan stasiun, dimana $1=<1 \mathrm{~km}, 2=1-2 \mathrm{~km}, 3=3-4 \mathrm{~km}$.

- X2 : Waktu tempuh perjalanan, dimana $1=<30$ menit, $2=30-60$ menit, $3=1-1,5 \mathrm{jam}, 4=$ 1,5- 2 jam.

- $\mathrm{X}_{3}$ : Biaya Perjalanan, dimana $1=<\mathrm{Rp} 20.000,2=>\mathrm{Rp} .20 .000$

- X4 : Keberadaan angkutan/feeder dari/ke stasiun menuju tempat aktivitas, dimana $1=$ Tidak ada, 2 = Ada.

- X5 : Status Pekerjaan dimana 1=Pegawai swasta/karyawan, $2=$ mahasiswa, $3=$ wiraswasta, 4= pedagang, 5=IRT, 6= PNS

Untuk melihat kemungkinan peralihan pengguna, sebelum dimasukkan ke dalam model, terlebih dahulu harus mencari nilai rata-rata dari variabel berdasarkan data responden. Hasil nilai rata-rata variabel dapat dilihat pada tabel VII.

TABEL VII

NILAI MEAN, MEDIAN DAN MODE DARI POTENSI PENGGUNA

\begin{tabular}{|c|l|r|r|r|}
\hline No & \multicolumn{1}{|c|}{ Variabel } & \multicolumn{1}{c|}{ Mean } & \multicolumn{1}{c|}{ Median } & \multicolumn{1}{c|}{ Mode } \\
\hline 1 & Jarak pemukiman dengan stasiun & 1.72 & 2 & 1 \\
\hline 2 & Waktu tempuh perjalanan & 1.89 & 2 & 2 \\
\hline 3 & Biaya Perjalanan & 1.33 & 1 & 1 \\
\hline 4 & Status pekerjaan & 2.39 & 1.5 & 1 \\
\hline 5 & Keberadaan angkutan/feeder dari/ke stasiun & 1.77 & 2 & 2 \\
\hline
\end{tabular}

Sumber: Analisis data, 2016 
Dari hasil analisis pada tabel 4-23 diperoleh bahwa nilai $X_{1}=1, X_{2}=2, X_{3}=1, X_{4}=1, X_{5}=2$, kemudian dimasukkan ke dalam model, yaitu sebagai berikut:

$$
\begin{aligned}
& \ln \left(\frac{P}{1-P}\right)=9,629-1,582(1)-1,644(2)-1,578(1)-1,, 532(1)+0,345(2) \\
& \ln \left(\frac{P}{1-P}\right)=2,339 \rightarrow 10,371 \\
& \left(\frac{P}{1-P}\right)=P(1-P) \times 10,371 \rightarrow P=0,91
\end{aligned}
$$

Nilai $\mathrm{P}$ yang besarnya 0,91 menunjukkan bahwa potensi beralihnya pengguna moda transportasi menjadi pengguna layanan kereta api adalah sebesar 91\%. Angka ini menunjukkan bahwa mayoritas penduduk Pabuaran memiliki kemungkinan yang sangat besar untuk dapat beralih menggunakan layanan kereta api di stasiun Cibinong.

Dari hasil regresi pada tabel VI dapat dilihat bahwa koefisien ß variabel jarak pemukiman sebesar $-1,582$ dengan signifikansi uji $t<5 \%(0,05)$ yaitu sebesar 0,000 . Hal ini berarti variabel jarak pemukiman signifikan berpengaruh terhadap kesediaan penduduk untuk menggunakan layanan kereta komuter. Semakin dekat jarak pemukiman dengan stasiun kereta maka semakin besar peluang penduduk yang bermukim di daerah tersebut untuk menggunakan layanan kereta di stasiun Ciibinong.

Koefisien $\beta$ variabel waktu tempuh perjalanan sebesar $-1,644$ dengan signifikansi uji $t<5 \%$ $(0,05)$ yaitu sebesar 0,004 . Hal ini berarti bahwa waktu tempuh perjalanan signifikan berpengaruh terhadap kesediaan penduduk untuk menggunakan layanan kereta komuter. Masyarakat akan memilih menggunakan moda transportasi yang dapat menghemat waktu perjalanan atau mempersingkat waktu perjalanan menuju tempat beraktivitas setiap harinya. Koefisien $ß$ variabel biaya perjalanan adalah sebesar $-1,578$ dengan signifikansi uji t $<5 \%(0,05)$ yaitu sebesar 0,012, hal ini berarti bahwa biaya perjalanan signifikan berpengaruh terhadap kesediaan penduduk untuk menggunakan layanan kereta komuter. Dengan kata lain penduduk sebelum memilih menggunakan moda transportasi selalu mempertimbangkan mengenai biaya perjalanan yang akan dikeluarkan. Mereka cenderung untuk menggunakan moda yang dapat menghemat biaya. Dalam hal ini penggunaan layanan kereta komuter relatif lebih murah dari moda transportasi lainnya.

Koefisien ß variabel keberadaan angkutan/feeder dari/ke stasiun adalah sebesar $-1,532$ dengan signifikansi uji $t<5 \%(0,05)$ yaitu sebesar 0,032 , hal ini berarti bahwa keberadaan angkutan/feeder signifikan berpengaruh terhadap kesediaan penduduk untuk menggunakan layanan kereta komuter. Keberadaan angkutan/feeder akan mempermudah pengguna untuk menjangkau tempat aktivitasnya setiap hari begitu juga sebaliknya.

Koefisien $ß$ variabel status pekerjaan adalah sebesar 0,345 dengan signifikansi uji $t<5 \%(0,05)$ yaitu sebesar 0,029 hal ini berarti bahwa status pekerjaan penduduk berpengaruh positif dan signifikan berpengaruh terhadap kesediaan penduduk untuk menggunakan layanan kereta komuter. Penduduk Pabuaran yang dominan bekerja sebagai karyawan perusahaan sangat membutuhkan moda transportasi yang dapat memenuhi kebutuhan pergerakan mereka setiap saat, bebas dari masalah kemacetan sehingga dapat mengefisienkan perjalanan mereka ke tempat aktivitas. 
Rosnaeni | Analisis Pemilihan Moda Transportasi Penduduk Kelurahan Pabuaran-Cibinong Pasca Pengoperasian Kereta Komuter (KRL) Jalur Nambo (Cibinong) - Citayam - Jakarta

\section{KESIMPULAN}

Kelurahan Pabuaran, Cibinong merupakan salah satu daerah pinggiran yang memiliki bangkitan perjalanan ke pusat kota yang sangat besar. Penduduk Pabuaran yang di dominasi oleh karyawan/karyawati perusahaan swasta, pegawai negeri sipil yang berada di daerah Jakarta setiap pagi melakukan perjalanan ketempat bekerja sebelum jam 08.00 pagi, dengan kondisi jalan raya ke arah Jakarta yang setiap hari mengalami masalah kemacetan, sehingga mereka membutuhkan moda transportasi yang bisa menghemat waktu perjalanan mereka ke tempat bekerja ataupun sebaliknya setiap harinya. untuk mengatasi masalah transportasi yang akan timbul akibat bangkitan perjalanan tersebut, maka pemerintah mengoperasikan layanan kereta komuter jalur Nambo (Cibinong) - Citayam - Jakarta Kota untuk melayani pergerakan penduduk sekitar.

Sejak pengoperasian layanan kereta komuter di stasiun Cibinong, diikuti dengan perubahan pemilihan moda transportasi penduduk Pabuaran, Cibinong. Akan tetapi masih terdapat persaingan antara pengguna layanan kereta komuter dengan pengguna motor dalam beraktivitas. Meskipun demikian, berdasarkan hasil analisis metode binary logistic diketahui bahwa peluang beralihnya pengguna kendaraan pribadi menjadi pengguna layanan kereta api adalah sebesar $91 \%$. Peluang perubahan pemilihan moda ini dapat terwujud jika dilakukan beberapa upaya untuk peningkatan kualitas pelayanan kereta komuter pada stasiun Cibinong, baik dari segi frekuensi perjalanan, akses menuju stasiun, penataan fasilitas parkir dan lain-lain.

\section{DAFTAR PUSTAKA}

Bhatta, B.P., Larsen, O.I., 2011. Errors in variables in multinomial choice modeling: a simulation study applied to a multinomial logit model of travel mode choice.Transport Policy 18, 326-335.

BPS, Kabupaten Bogor. 2014. Kecamatan Cibinong dalam Angka. Bogor.

Can, V.V., 2013. Estimation of travel mode choice for domestic tourists to Nha Trang using the multinomial probit model. Transportation Research. Part A 49, 149-159.

Casseta, Ennio. 2009. Transportation system Analysis: Models and Application. London: Springer.

Habib, K.M.N., Sasic, A., 2014. A GEV model with scale heterogeneity for investigating the role of mobility tool ownership in peak period non-work travel mode choices. J. Choice Model. 10, 46-59.

Hunecke, M., Haustein, S., Grischkat, S., Bohler, S., 2007. Psychological, sociodemographic, and infrastructural factors as determinants of ecological impact caused by mobility behavior. J. Environ. Psychol. 27 (4), 277-292.

J. Supranto. 2003. Metode Penelitian Hukum dan Statistik. Jakarta: PT. Rineka Cipta.

Lee,C.,Zhu,X.,Yoon,J.,Varni,J.W.,2013.Beyond distance: children's school travel mode choice. Ann.Behav.Med.45(1),s55-s77.

McMillan,T.E.,2007.The relative influence of urban for monachild's travel mode to school. Transp.Res.PartA:PolicyPract.41(1),69-79.

Miro, Fidel. 2002, Perencanaan Transportasi. Jakarta: Erlangga.

Panter,J.R.,Jones,A.P.,vanSluijs,E.M.F.,Griffin,S.J.,2010b. Attitudes, social support and environmental perceptions as predictors of active commuting in school children. $J$. Epidemiol.Community Health 64,41-48. 
Setijowarno, D. dan Frazila, R.B, 2001, Pengantar Sistem Transportasi. Edisi ke-I Semarang: Penerbit Universitas Katolik Soegijapranata.

Sugiyono. 2010. Metode Penelitian Kuantitatif kualitatif \& RND. Bandung: Penerbit Alpabeta. Tamin, Ofyar Z. (1997), Perencanaan dan Permodelan Transportasi. Bandung: Penerbit ITB.

Vega, A., Reynolds-Feighan, A., 2009. A methodological framework for the study of residential location and travel-to-work mode choice under central and suburban employment destination patterns. Transp. Res. Part A 43, 401-419.

Vuchic V. 2007. Urban Transit Systems and Technology. New York: John Wiley \& Sons.

Whalen, K.E., Páez, A., Carrasco, J.A., 2013. Mode choice of university students commuting to school and the role of active travel. J. Transp. Geogr. 31, 132-142.

Yandong, Yang. 2014. Development of the regional freight transportation demand prediction models based on the regression analysis methods. J. Neurocomputing158 (2015) 42-47. 